Check for updates

Cite this: Chem. Commun., 2020, 56, 7163

Received 15th April 2020,

Accepted 22nd May 2020

DOI: $10.1039 / d 0 c c 02733 b$

rsc.li/chemcomm

\section{Novel hybrid aluminium(III)-catalen complexes as highly active catalysts for lactide polymerisation: towards industrial relevance $\uparrow$}

\author{
Jack Payne, ${ }^{\text {ab }}$ Paul McKeown, (D) ${ }^{b}$ Gabriele Kociok-Köhn (DD ${ }^{b}$ and \\ Matthew D. Jones (D) *ab
}

\begin{abstract}
Herein, we report a series of highly active $\mathrm{Al}(\mathrm{III})$-complexes based on a novel hybrid ligand: the catalen. Their application in the production of polylactide under both solution, and industrially preferred melt conditions, is demonstrated. Potential structural diversification to broaden initiator scope is discussed.
\end{abstract}

Whilst plastics remain deeply embedded in modern day society, growing environmental concerns within industry has stimulated considerable research into renewable alternatives. ${ }^{1}$ Polylactide (PLA) has received significant commercial interest owing to its green credentials and ability to compete with existing petroleumbased plastics, particularly within the packaging sector. ${ }^{2,3}$ Industrially, PLA is produced from L-lactide under solvent-free conditions, relying on a $\mathrm{Sn}(\mathrm{Oct})_{2}$ catalyst. ${ }^{4}$ However, toxicity concerns surrounding $\mathrm{Sn}(\mathrm{Iv})$ has created an appetite for biocompatible and sustainable alternatives. Initiators based on $\mathrm{Mg}(\mathrm{II})^{5-8}$ and $\mathrm{Zn}(\mathrm{II})^{5-7,9-16}$ have thus been extensively reported, but those pertinent to this report exploit $\mathrm{Al}(\mathrm{III})$ bearing tetradentate bis(phenolate) ligands. Early examples by Spassky et al. ${ }^{17}$ and Feijen et al. ${ }^{18,19}$ relied on chiral salen-based initiators, achieving exceptional isoselectivity $\left(P_{\mathrm{r}}=0.05-0.12\right)$. Development of the field saw the emergence of achiral initiators retaining the salen pro-ligand functionality. ${ }^{20-25}$ Ligand scope significantly expanded with the emergence of subsequently reduced derivatisations, namely salalens ${ }^{26-30}$ and salans. ${ }^{31-35}$ Such ligand classes are traditionally easy to synthesise and functionally versatile, providing significant scope for catalyst fine-tuning. However, whilst it is clear the field has developed significantly within the last 20 years, particularly from a stereoselectivity standpoint, $\mathrm{Al}(\mathrm{mI})$ complexes remain limited by their poor activity, often requiring elevated conditions $\left(T>70{ }^{\circ} \mathrm{C}\right)$ and high catalyst loadings

\footnotetext{
${ }^{a}$ Centre for Sustainable and Circular Technologies, University of Bath,

Claverton Down, Bath, BA2 7AY, UK

${ }^{b}$ Department of Chemistry, University of Bath, Claverton Down, Bath, BA2 7AY, UK. E-mail:mj205@bath.ac.uk

$\dagger$ Electronic supplementary information (ESI) available: Full details of the experimental protocols with selected spectra and raw data. CCDC 1996836-1996840. For ESI and crystallographic data in CIF or other electronic format see DOI: $10.1039 / \mathrm{d} 0 \mathrm{cc} 02733 \mathrm{~b}$
}

( $\sim 1 \mathrm{~mol} \%$ ) to be appreciably active. Recently, Romain et al. ${ }^{36,37}$ reported the first example of a series of highly active $\mathrm{Al}(\mathrm{III})$-complexes bearing a catam-type ligand scaffold. Exceptional activity was observed, achieving full conversion to PLA with a slight isotactic bias $\left(P_{\mathrm{r}}=0.4\right)$ within 90 minutes at room temperature (RT) $\{\mathrm{THF}$, $[$ rac-LA]: [I]: $[\mathrm{BnOH}]=100: 1: 1\}$. Interestingly, shifting from an ethyl to substituted propyl backbone had significant ramifications on stereoselectivity, producing highly heterotactic PLA $\left(P_{\mathrm{r}}=0.9\right)$, highlighting the importance of structure-activity relationships. However, producing highly isotactic PLA, whilst retaining activity, remains a prevalent challenge in the field, particularly under industrially preferred melt conditions. Whilst highly efficient metal-free organocatalysts have also been reported in the ROP of rac-LA in solution, retaining high activity in the melt remains a major limitation, with $\mathrm{Al}(\mathrm{III})$-complexes a possible solution. ${ }^{1,38}$

Herein, we report the preparation and characterisation of a series of highly active $\mathrm{Al}(\mathrm{III})$-complexes based on a novel hybrid ligand framework: the catalen. Their application in the ROP of $r a c$-LA in solution, and under industrially preferred melt conditions, is discussed.

The catalen ligands, and subsequently derived $\mathrm{Al}(\mathrm{III})$-complexes, were prepared under mild conditions as depicted in Scheme 1. Despite significant effort, attempts to isolate $\mathrm{Al}(2) \mathrm{Me}$ proved unsuccessful. The solid-state structure of all complexes prepared was determined via single crystal X-ray diffraction (XRD), with the exception of $\mathrm{Al}(\mathbf{3}) \mathrm{Me}$ (Fig. 1). $\mathrm{Al}(\mathbf{1}) \mathrm{Me}$ exhibited a distorted trigonal bipyramidal geometry $\left(\tau_{5}=0.62\right)$, whilst $[\mathrm{Al}(1-3)\{\mathrm{OBn}\}]_{2}$ conformed reasonably well with an octahedral geometry $\left\{[\mathrm{Al}(2)\{\mathrm{OBn}\}]_{2}\right.$ : $\left.\mathrm{O}(1)-\mathrm{Al}(1)-\mathrm{N}(2), \mathrm{O}(2)-\mathrm{Al}(1)-\mathrm{N}(1)=88.2(3), 172.2(3)^{\circ}\right\}$.

An $\mathrm{Al}(1)-\mathrm{N}(1)$ bond length of $c a .2 \AA$ confirmed retention of the imine functionality on coordination to the $\mathrm{Al}(\mathrm{III})$ centre for all complexes. The methoxy bridge analogue of $[\operatorname{Al}(\mathbf{1})\{\mathrm{OBn}\}]_{2}$ was isolated on exposure of $\mathrm{Al}(\mathbf{1}) \mathrm{Me}$ to air, presumably through migration of the terminal -Me, and characterised by XRD but not pursued in polymerisation studies (see ESI $\dagger$ ). ${ }^{1} \mathrm{H}$ NMR spectroscopic analysis of $[\mathrm{Al}(\mathbf{1}-\mathbf{3})\{\mathrm{OBn}\}]_{2}$ revealed characteristic singlet peaks at $c a . \delta=7.50$ and $5.50 \mathrm{ppm}$ corresponding to ArCHN and $-\mathrm{NH}$ resonances respectively. The $-\mathrm{NH}$ resonance 


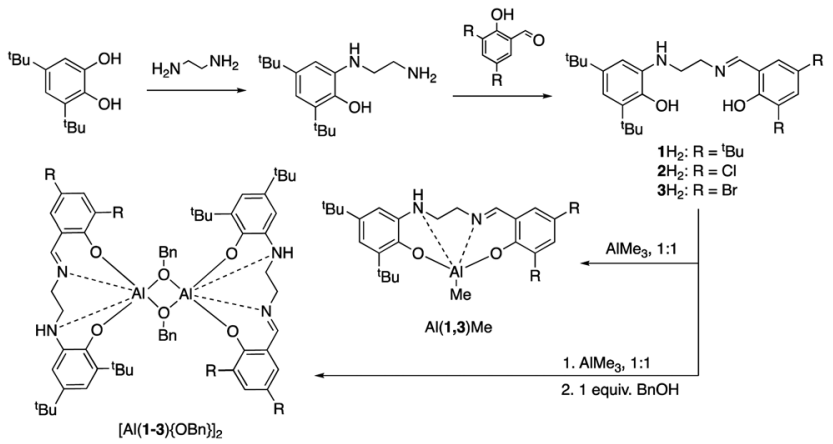

Scheme 1 Ligands and $\mathrm{Al}($ III)-complexes prepared in this study.

was absent in $\mathrm{Al}(\mathbf{1}, \mathbf{3}) \mathrm{Me}$, presumably due to enhanced structural fluxionality. More interestingly, the $-\mathrm{OBn}\left\{\mathrm{CH}_{2}\right\}$ resonances appeared as two distinct diasterotopic doublets, indicating $[\mathrm{Al}(1-3)\{\mathrm{OBn}\}]_{2}$ to be asymmetric with the potential to exert catalytic-site stereocontrol (see ESI $\dagger$ ). ${ }^{13} \mathrm{C}\left\{{ }^{1} \mathrm{H}\right\}$ NMR spectroscopic analysis was consistent with XRD and ${ }^{1} \mathrm{H}$ NMR spectroscopic analysis, observing poor signal resolution for $[\mathrm{Al}(1-3)\{\mathrm{OBn}\}]_{2}$, indicative of fluxionality, confounded by poor solubility. Diffusional ordered spectroscopy (DOSY) analysis of a monomeric $v$ s. dimeric system comparison, namely $\mathrm{Al}(\mathbf{1}) \mathrm{Me}$ and $[\mathrm{Al}(\mathbf{1})\{\mathrm{OBn}\}]_{2}$ respectively, confirmed the species to exist exclusively in solution with diffusion constants $(D)$ of 0.66 and $0.46 \times 10^{-9} \mathrm{~m}^{2} \mathrm{~s}^{-1}$ respectively (see ESI $\dagger$ ), with no aggregation observed. These diffusion coefficients are in good agreement with the predicted molecular weights $\{\mathrm{Al}(\mathbf{1}) \mathrm{Me}$, $[\mathrm{Al}(1)\{\mathrm{OBn}\}]_{2}: M_{\mathrm{r}}=520.74,1225.66 \mathrm{~g} \mathrm{~mol}^{-1} ; M_{\mathrm{r}, \mathrm{DOSY}}=527.7$, $\left.1173.2 \mathrm{~g} \mathrm{~mol}^{-1}\right\} .^{39} \mathrm{All} \mathrm{Al(III)}$-complexes were in generally good agreement with elemental analysis (EA) data obtained, although $C \%$ values slightly lower than expected were observed for $\mathrm{Al}(\mathbf{1}, \mathbf{3}) \mathrm{Me}$ and $[\mathrm{Al}(\mathbf{1}-\mathbf{2})\{\mathrm{OBn}\}]_{2}$, due to suspected hydrolysis and the presence of $\mathrm{H}_{2} \mathrm{O}$ respectively.

All complexes were trialed in the ROP of rac-LA in solution $\left(25\right.$ and $80{ }^{\circ} \mathrm{C}$ ) and under industrially preferred melt conditions $\left(130\right.$ and $180^{\circ} \mathrm{C}$ ) in the absence of solvent (Tables 1 and 2). $[\mathrm{Al}(1-3)\{\mathrm{OBn}\}]_{2}$ were treated as monomeric such that one -OBn moiety was associated per $\mathrm{Al}$ centre. Unless otherwise stated, it is proposed the polymerisation proceeded via the classical coordination mechanism since $[\mathrm{Al}(\mathbf{1}-\mathbf{3})\{\mathrm{OBn}\}]_{2}$ were derived from $\mathrm{Al}(\mathbf{1}-3) \mathrm{Me}$ on reaction with $\mathrm{BnOH}$. It was envisaged introducing the 'catam' component into the ligand backbone would impart enhanced activity, whilst retention of the 'salen' component would provide rigidity, and therefore the potential to exert stereocontrol.

All complexes were highly active in the melt, atypical of traditional aluminium-based systems..$^{18,19,30,31} \mathrm{Al}(\mathbf{1}) \mathrm{Me}$ exhibited fair polymerisation control, affording atactic PLA of moderate dispersities $(D=1.35)$. Comparable activity and superior $M_{\mathrm{n}}$ control was observed in the analogous $[\mathrm{Al}(\mathbf{1})\{\mathrm{OBn}\}]_{2}$ system. $\mathrm{Al}(\mathbf{3}) \mathrm{Me}$ exhibited superior activity compared to $\mathrm{Al}(\mathbf{1}) \mathrm{Me}$, presumably due to a less hindered and more Lewis acidic $\mathrm{Al}(\mathrm{III})$ centre. Remarkably, a TOF of $45300 \mathrm{~h}^{-1}$ (Table 1, entry 3) was observed, the highest reported thus far for aluminium, though literature studies in the melt remain limited despite industrial relevance. ${ }^{18,19,30,31,37}$ Whilst moderately heterotactic PLA $\left(P_{\mathrm{r}}=0.64\right)$ was produced, poor $M_{\mathrm{n}}$ control (relative to theoretical values) and broad dispersities $(\theta=1.81)$ were observed, implying $k_{\mathrm{p}} \gg k_{i}$, which subsequently inhibited homogenous polymerisation. Moderate heterotacticity $\left(P_{\mathrm{r}}=0.64-0.65\right)$ and poor control $\left(M_{\mathrm{n}}=93100-146200 \mathrm{~g} \mathrm{~mol}^{-1}\right)$ was retained for $[\mathrm{Al}(2-3)\{\mathrm{OBn}\}]_{2}$ despite a reduction in activity. It is suggested the introduction of an electron-withdrawing ligand scaffold inhibits catalyst dissociation under these conditions, essentially maintaining the dimeric structure, such that less active species is available. A reduction in activity down the $[\mathrm{Al}(\mathbf{1}-\mathbf{3})\{\mathrm{OBn}\}]_{2}$ series, contrary to that noted for $\mathrm{Al}(\mathbf{1}, \mathbf{3}) \mathrm{Me}$, can likely be attributed to said dissociation effect, confounded by poorer solubility in the melt. The activity of $\mathrm{Al}(\mathbf{1}, \mathbf{3}) \mathrm{Me}$ and the $[\mathrm{Al}(\mathbf{3})\{\mathrm{OBn}\}]_{2}$ was also investigated under industrially relevant catalyst and monomer loadings, targeting PLA of $M_{\mathrm{n}}$ comparable to commercial products $\left(M_{\mathrm{n}} \sim 45000 \mathrm{~g} \mathrm{~mol}^{-1}\right)$. Promisingly, high activity in the melt was retained upon reducing the catalyst loading to $0.033 \mathrm{~mol} \%$. To the best of our knowledge, this is the first example of aluminium-based complexes exhibiting significant activity under industrially relevant conditions. Prolonged reaction times resulted in polymer of narrower dispersities $(\theta=1.24-1.35)$ with a lower than expected $M_{\mathrm{n}}\left(13700-14700 \mathrm{~g} \mathrm{~mol}^{-1}\right)$. For $[\mathrm{Al}(3)\{\mathrm{OBn}\}]_{2}$, it is proposed an increase in temperature assists the dissociation of $[\mathrm{Al}(3)\{\mathrm{OBn}\}]_{2}$, resulting in superior $M_{\mathrm{n}}$ control (Table 1, entry 8).

The remarkable activity exhibited by the $\mathrm{Al}(\mathrm{III})$-complexes in the melt was retained in solution, particularly at elevated
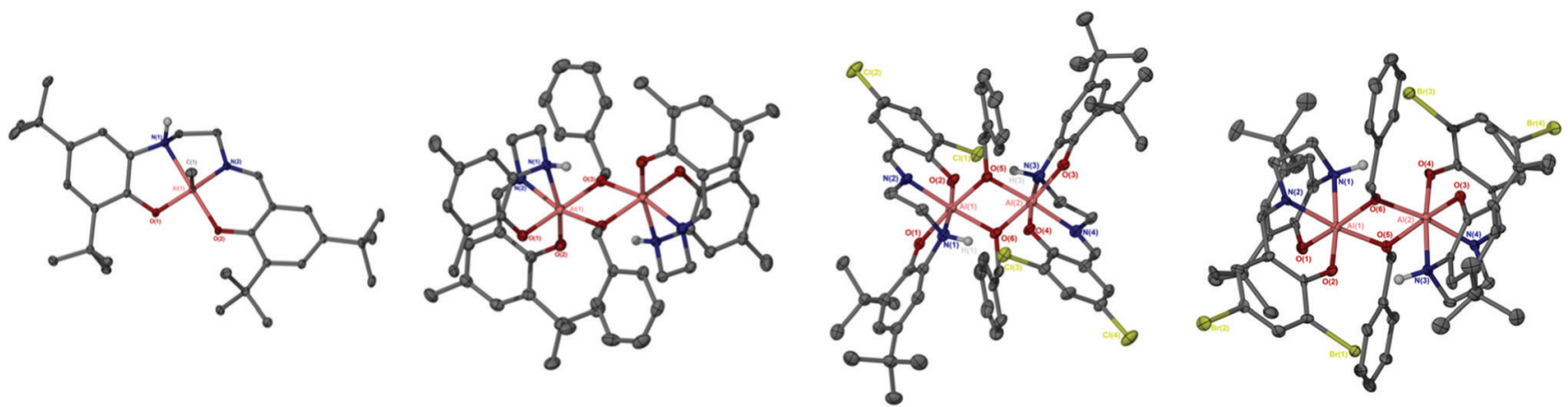

Fig. 1 Solid state structures for $\mathrm{Al}(\mathbf{1}) \mathrm{Me}$ and $[\mathrm{Al}(\mathbf{1}-\mathbf{3})\{\mathrm{OBn}\}]_{2}$ from left to right with ellipsoids shown at $30 \%$ probability level and all hydrogens omitted for clarity except those bound to nitrogen atoms. For $[\mathrm{Al}(\mathbf{1})\{\mathrm{OBn}\}]_{2},{ }^{\mathrm{t}} \mathrm{Bu}$ methyl groups have also been omitted for clarity. 
Table 1 Melt polymerisation of rac-LA using Al(III)-complexes

\begin{tabular}{|c|c|c|c|c|c|c|c|}
\hline Init. & Time/min & {$[r a c-\mathrm{LA}]:[\mathrm{Al}]:[\mathrm{BnOX}]$} & Conv. $^{a} / \%$ & $M_{\mathrm{n}, \text { theo }}{ }^{b} / \mathrm{g} \mathrm{mol}^{-1}$ & $M_{\mathrm{n}}{ }^{c} / \mathrm{g} \mathrm{mol}^{-1}$ & $\Xi^{c}$ & $P_{\mathrm{r}}^{d}$ \\
\hline & 19 & $3000: 1: 10$ & 83 & 35950 & 14700 & 1.35 & 0.46 \\
\hline$[\mathrm{Al}(\mathbf{1})\{\mathrm{OBn}\}]_{2}$ & 2 & $300: 1: 1$ & 88 & 38100 & 40900 & 1.42 & 0.46 \\
\hline$[\mathrm{Al}(2)\{\mathrm{OBn}\}]_{2}$ & 5 & $300: 1: 1$ & 76 & 32950 & 146200 & 1.52 & 0.64 \\
\hline$[\mathrm{Al}(\mathbf{3})\{\mathrm{OBn}\}]_{2}$ & 8 & $300: 1: 1$ & 74 & 32100 & 93100 & 1.39 & 0.65 \\
\hline
\end{tabular}

Conditions: $r a c$-LA $(1.0 \mathrm{~g})$, solvent free $\left(130{ }^{\circ} \mathrm{C}\right) .{ }^{a}$ Determined via ${ }^{1} \mathrm{H}$ NMR spectroscopy. ${ }^{b}$ Theoretical average number molecular weight $\left(M_{\mathrm{n}}\right)$ dependent on conversion and co-initiator added $\left\{\left(M_{\mathrm{n}, \mathrm{LA}} \times 3 \times \%_{\text {conv }}\right)+M_{\mathrm{n}, \mathrm{BnOH}}\right\} .{ }^{c}$ Determined via GPC analysis (in THF). ${ }^{d}$ Determined via homonuclear decoupled NMR spectroscopy. ${ }^{e} 9$ equivalents of $\mathrm{BnOH}$ added to achieve $\{[\mathrm{Al}]:[\mathrm{BnOH}]=1: 10\}$. A correction factor of 0.58 has been applied to reported $M_{\mathrm{n}}$ values. ${ }^{40}$

Table 2 Solution polymerisation of rac-LA using Al(III)-complexes

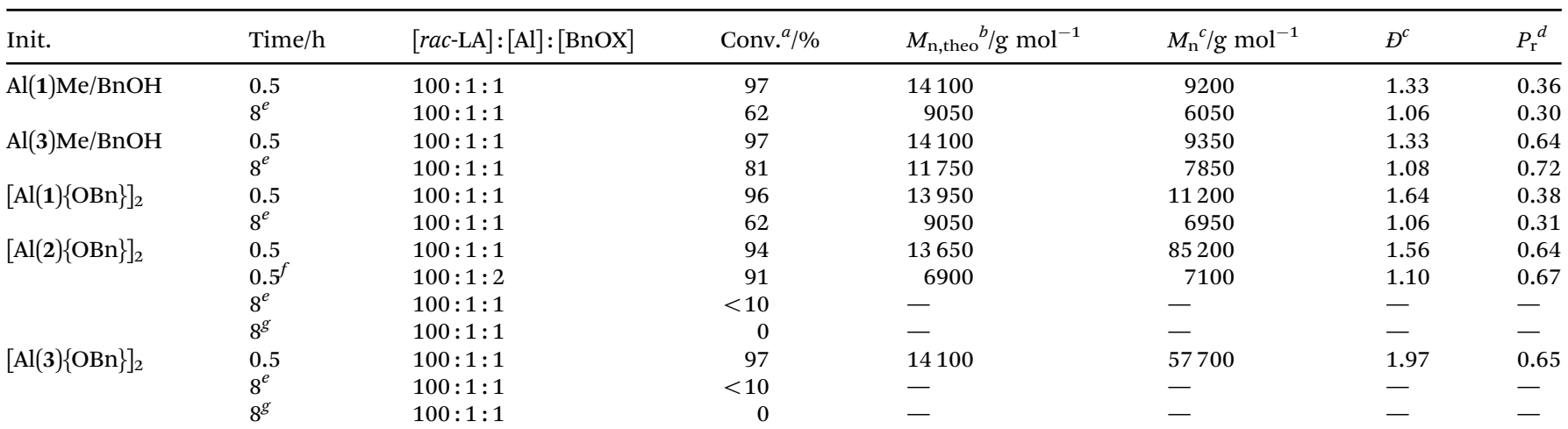

Conditions: rac-LA $(0.5 \mathrm{~g})$, solvent (toluene, $\left.80{ }^{\circ} \mathrm{C}\right) .{ }^{a}$ Determined via ${ }^{1} \mathrm{H}$ NMR spectroscopy. ${ }^{b}$ Theoretical average number molecular weight $\left(M_{\mathrm{n}}\right)$ dependent on conversion and co-initiator added $\left\{\left(M_{\mathrm{n}, \mathrm{LA}} \times \%_{\text {conv }}\right)+M_{\mathrm{n}, \mathrm{BnOH}}\right\} .{ }^{c}$ Determined via GPC analysis (in THF). ${ }^{d}$ Determined via homonuclear decoupled NMR spectroscopy. ${ }^{e}$ RT $\left(25^{\circ} \mathrm{C}\right)$ in DCM. ${ }^{f} 1$ equiv. of BnOH added to achieve $\{[\mathrm{Al}]:[\mathrm{BnOH}]=1: 2\} .{ }^{g} \mathrm{RT}\left(25{ }^{\circ} \mathrm{C}\right)$ in THF. $M_{\mathrm{n}}$, $D$ and $P_{\mathrm{r}}$ values for $[\mathrm{Al}(2-3)\{\mathrm{OBn}\}]_{2}$ at RT in DCM could not be determined due to insufficient polymeric material being isolated. A correction factor of 0.58 has been applied to reported $M_{\mathrm{n}}$ values. $^{40}$

conditions. All complexes achieved $>94 \%$ conversion within 30 minutes at $80{ }^{\circ} \mathrm{C}$ (Table 2). Previously reported salen ${ }^{23}$ and salan $^{32}$ systems analogous to $\mathrm{Al}(\mathbf{1}) \mathrm{Me}$ achieved $19 \%$ and $77 \%$ conversion after 3 and 5 days respectively toluene, $70{ }^{\circ} \mathrm{C}$, $[\mathrm{rac}-\mathrm{LA}]:[\mathrm{I}]:[\mathrm{BnOH}]=100: 1: 1\} .{ }^{36}$ Romain et al. ${ }^{37}$ have previously attributed the enhanced reactivity of the catam to the presence of an $-\mathrm{NH}$ hydrogen donor, which readily interacts with the reactive species. Generally, fair $M_{n}$ control and moderate dispersities $(D=1.33-1.64)$ were observed, with the exception of $[\mathrm{Al}(2-3)\{\mathrm{OBn}\}]_{2}$, consistent with the melt. The addition of 1 equiv. of $\mathrm{BnOH}$ resulted in significantly enhanced $M_{\mathrm{n}}$ and $D$ control for $[\mathrm{Al}(2)\{\mathrm{OBn}\}]_{2}$ at $80{ }^{\circ} \mathrm{C}$, suggesting a more efficient initiation process (Table 2, entry 8; see ESI $\dagger$ ). General reactivity trends discussed for $\mathrm{Al}(\mathbf{1}, \mathbf{3}) \mathrm{Me}$ were retained in solution, and could be extended to the dimeric series owing to enhanced solubility under these conditions. The production of moderately isotactic PLA $\left(P_{\mathrm{r}}=0.36\right)$ was observed with an electron-donating catalen backbone bearing the ${ }^{t} \mathrm{Bu}$ substituents. Adopting electron-withdrawing substituents resulted in a shift to moderate heteroselectivity $\left(P_{\mathrm{r}}=0.64-0.65\right)$, highlighting the importance of structure-activity relationships. Enhanced stereoselectivity $\left(P_{\mathrm{r}}=0.30-0.72\right)$ and narrower dispersities $(D=1.06-1.09)$ were observed at RT in DCM, whilst reasonable $M_{\mathrm{n}}$ control was retained, achieving between $62-81 \%$ conversion within $8 \mathrm{~h}$
$\left(\mathrm{TOF}=8-10 \mathrm{~h}^{-1}\right)$. Prior to this, very few examples of aluminiumbased complexes exhibiting appreciable activity at room temperature have been reported. ${ }^{36,37,41-44}$ Moreover, near identical stereoselectivities between $\mathrm{Al}(\mathbf{1}, \mathbf{3}) \mathrm{Me}$ and their dimeric counterparts suggests an identical active species. Since $\mathrm{Al}(\mathbf{1}, \mathbf{3}) \mathrm{Me}$ exhibit good polymerisation control under solution conditions, this implies $[\mathrm{Al}(\mathbf{1}-\mathbf{3})\{\mathrm{OBn}\}]_{2}$ dissociation to be kinetically limited. Slow and incomplete dissociation is supported by stability testing of $[\mathrm{Al}(2)\{\mathrm{OBn}\}]_{2}$ with $r a c$-LA in $\mathrm{CDCl}_{3}$, with the ${ }^{1} \mathrm{H}$ NMR remaining virtually unchanged after $24 \mathrm{~h}$ at RT (see ESI $\dagger$ ). Consequently, low activity was observed for $[\mathrm{Al}(2-3)\{\mathrm{OBn}\}]_{2}$ (Table 2, entries 9 and 12), which was exacerbated by poor catalyst solubility under the reaction conditions. However, such limitations associated with catalyst dissociation could be mitigated by forming the benzoxy-bridged species in situ, evidenced by $\mathrm{Al}(3) \mathrm{Me}$. Interestingly, no reaction occurred on substituting the solvent for THF, despite achieving complete dissolution, likely owing to competitive binding of the solvent with lactide. MALDI-ToF analysis of polymeric material produced using $[\mathrm{Al}(\mathbf{1})\{\mathrm{OBn}\}]_{2}$ (Table 2, entry 6) confirmed the polymer to be $-\mathrm{OBn}$ and $-\mathrm{H}$ end-capped. No secondary series were observed suggesting the polymerisation to be well-controlled in the absence of detrimental transesterification side reactions, consistent with the GPC data. No evidence of 
transesterification was observed for $[\mathrm{Al}(2)\{\mathrm{OBn}\}]_{2}$ in the presence of benzyl alcohol (Table 2, entry 8), suggesting the broader dispersities are a result of a slow initiation rate compared to propagation, likely due to limited complex dissociation (see ESI $\dagger$ ).

Since comparable solution polymerisation performance was observed between $\mathrm{Al}(\mathbf{1}, \mathbf{3}) \mathrm{Me}$ and their benzoxy-bridged counterparts, a kinetic study was pursued for $[\mathrm{Al}(1-3)\{\mathrm{OBn}\}]_{2}$ at $80{ }^{\circ} \mathrm{C}$ (see ESI $\dagger$ ). All complexes were observed to be extremely active, achieving $k_{\text {app }}$ values between (6.2-10.8) $\times 10^{-2} \mathrm{~min}^{-1}$. Interestingly, $[\mathrm{Al}(2)\{\mathrm{OBn}\}]_{2}$ exhibited the lowest activity $\left(k_{\text {app }}=6.2 \times\right.$ $10^{-2} \pm 0.0072 \mathrm{~min}^{-1}$ ) despite bearing the most electron withdrawing catalen backbone.

In conclusion, a series of highly active $\mathrm{Al}(\mathrm{III})$-complexes based on a novel catalen ligand framework have been reported. Extremely high activity in the melt was demonstrated, which was retained under solution conditions, with $\mathrm{Al}(3) \mathrm{Me}$ culminating in the most active aluminium-based system to date in the melt. Work is ongoing to optimise activity and stereocontrol via diversification of both the ligand and metal.

We wish to thank the University of Bath and $\mathrm{MC}_{2}$ for use of analysis facilities. We thank the EPSRC for funding (EP/L016354/1 - JP) and (EP/P016405/1 - PM).

\section{Conflicts of interest}

There are no conflicts to declare.

\section{References}

1 J. Payne, P. McKeown and M. D. Jones, Polym. Degrad. Stab., 2019, 165, 170-181.

2 J. Lunt, Polym. Degrad. Stab., 1998, 59, 145-152.

3 D. Garlotta, J. Polym. Environ., 2001, 9, 63-84.

4 O. Dechy-Cabaret, B. Martin-Vaca and D. Bourissou, Chem. Rev., 2004, 104, 6147-6176.

5 M. H. Chisholm, J. Gallucci and K. Phomphrai, Inorg. Chem., 2002, 41, 2785-2794.

6 B. M. Chamberlain, M. Cheng, D. R. Moore, T. M. Ovitt, E. B. Lobkovsky and G. W. Coates, J. Am. Chem. Soc., 2001, 123, 3229-3238.

7 P. McKeown, S. N. McCormick, M. F. Mahon and M. D. Jones, Polym. Chem., 2018, 9, 5339-5347.

8 T. Rosen, I. Goldberg, V. Venditto and M. Kol, J. Am. Chem. Soc., 2016, 138, 12041-12044.

9 D. E. Stasiw, A. M. Luke, T. Rosen, A. B. League, M. Mandal, B. D. Neisen, C. J. Cramer, M. Kol and W. B. Tolman, Inorg. Chem., 2017, 56, 14366-14372.

10 P. M. Schäfer, M. Fuchs, A. Ohligschläger, R. Rittinghaus, P. McKeown, E. Akin, M. Schmidt, A. Hoffmann, M. A. Liauw, M. D. Jones and S. Herres-Pawlis, ChemSusChem, 2017, 10, 3547-3556.

11 J. Börner, I. Dos Santos Vieira, A. Pawlis, A. Döring, D. Kuckling and S. Herres-Pawlis, Chem. - Eur. J., 2011, 17, 4507-4512.

12 J. Börner, U. Florke, K. Huber, A. Döring, D. Kuckling and S. HerresPawlis, Chem. - Eur. J., 2009, 15, 2362-2376.

13 Y. Gong and H. Ma, Chem. Commun., 2019, 55, 10112-10115.

14 A. Thevenon, C. Romain, M. S. Bennington, A. J. P. White, H. J. Davidson, S. Brooker and C. K. Williams, Angew. Chem., Int. Ed., 2016, 55, 8680-8685.
15 M. Cheng, A. B. Attygalle, E. B. Lobkovsky and G. W. Coates, J. Am. Chem. Soc., 1999, 121, 11583-11584.

16 J. Payne, P. McKeown, M. F. Mahon, E. A. C. Emanuelsson and M. D. Jones, Polym. Chem., 2020, 11, 2381-2389.

17 N. Spassky, M. Wisniewski, C. Pluta and A. LeBorgne, Macromol. Chem. Phys., 1996, 197, 2627-2637.

18 Z. Y. Zhong, P. J. Dijkstra and J. Feijen, Angew. Chem., Int. Ed., 2002, 41, 4510-4513.

19 Z. Zhong, P. J. Dijkstra and J. Feijen, J. Am. Chem. Soc., 2003, 125, 11291-11298.

20 M. Wisniewski, A. LeBorgne and N. Spassky, Macromol. Chem. Phys., 1997, 198, 1227-1238.

21 E. D. Cross, L. E. N. Allan, A. Decken and M. P. Shaver, J. Polym. Sci., Part A: Polym. Chem., 2013, 51, 1137-1146.

22 N. Nomura, R. Ishii, M. Akakura and K. Aoi, J. Am. Chem. Soc., 2002, 124, 5938-5939.

23 N. Nomura, R. Ishii, Y. Yamamoto and T. Kondo, Chem. - Eur. J., 2007, 13, 4433-4451.

24 H.-L. Chen, S. Dutta, P.-Y. Huang and C.-C. Lin, Organometallics, 2012, 31, 2016-2025.

25 P. Hormnirun, E. L. Marshall, V. C. Gibson, R. I. Pugh and A. J. P. White, Proc. Natl. Acad. Sci. U. S. A., 2006, 103, 15343-15348.

26 E. L. Whitelaw, G. Loraine, M. F. Mahon and M. D. Jones, Dalton Trans., 2011, 40, 11469-11473.

27 E. L. Whitelaw, M. F. Mahon and M. D. Jones, Inorg. Chem., 2010, 49, 7176-7181.

28 A. Pilone, K. Press, I. Goldberg, M. Kol, M. Mazzeo and M. Lamberti, J. Am. Chem. Soc., 2014, 136, 2940-2943.

29 P. McKeown, M. G. Davidson, J. P. Lowe, M. F. Mahon, L. H. Thomas, T. J. Woodman and M. D. Jones, Dalton Trans., 2016, 45, 5374-5387.

30 P. McKeown, M. G. Davidson, G. Kociok-Köhn and M. D. Jones, Chem. Commun., 2016, 52, 10431-10434.

31 M. D. Jones, L. Brady, P. McKeown, A. Buchard, P. M. Schafer, L. H. Thomas, M. F. Mahon, T. J. Woodman and J. P. Lowe, Chem. Sci., 2015, 6, 5034-5039.

32 P. Hormnirun, E. L. Marshall, V. C. Gibson, A. J. P. White and D. J. Williams, J. Am. Chem. Soc., 2004, 126, 2688-2689.

33 H. Du, A. H. Velders, P. J. Dijkstra, J. Sun, Z. Zhong, X. Chen and J. Feijen, Chem. - Eur. J., 2009, 15, 9836-9845.

34 K. Press, I. Goldberg and M. Kol, Angew. Chem., Int. Ed., 2015, 54, 14858-14861.

35 R. Hador, A. Botta, V. Venditto, S. Lipstman, I. Goldberg and M. Kol, Angew. Chem., Int. Ed., 2019, 58, 14679-14685.

36 S. Gesslbauer, H. Cheek, A. J. P. White and C. Romain, Dalton Trans., 2018, 47, 10410-10414.

37 S. Gesslbauer, R. Savela, Y. Chen, A. J. P. White and C. Romain, ACS Catal., 2019, 9, 7912-7920.

38 N. E. Kamber, W. Jeong, R. M. Waymouth, R. C. Pratt, B. G. G. Lohmeijer and J. L. Hedrick, Chem. Rev., 2007, 107, 5813-5840.

39 R. Evans, Z. Deng, A. K. Rogerson, A. S. McLachlan, J. J. Richards, M. Nilsson and G. A. Morris, Angew. Chem., Int. Ed., 2013, 52, 3199-3202.

40 J. Baran, A. Duda, A. Kowalski, R. Szymanski and S. Penczek, Macromol. Rapid Commun., 1997, 18, 325-333.

41 F. Hild, P. Haquette, L. Brelot and S. Dagorne, Dalton Trans., 2010, 39, 533-540.

42 C. Robert, T. E. Schmid, V. Richard, P. Haquette, S. K. Raman, M.-N. Rager, R. M. Gauvin, Y. Morin, X. Trivelli, V. Guérineau, I. del Rosal, L. Maron and C. M. Thomas, J. Am. Chem. Soc., 2017, 139, 6217-6225.

43 S. Praban, P. Piromjitpong, V. Balasanthiran, S. Jayaraj, M. H. Chisholm, J. Tantirungrotechai and K. Phomphrai, Dalton Trans., 2019, 48, 3223-3230.

44 M. Anker, C. Balasanthiran, V. Balasanthiran, M. H. Chisholm, S. Jayaraj, K. Mathieu, P. Piromjitpong, S. Praban, B. Raya and W. J. Simonsick, Dalton Trans., 2017, 46, 5938-5945. 